\title{
La mentorización Intercultural - El proyecto INTO
}

\section{Intercultural Mentoring - INTO Project}

\section{Editorial de la revista}

Francisco José García-Peñalvo

Departamento de Informática y Automática, Instituto de Ciencias de la Educación, Grupo GRIAL, Director Científico, Editor-In-Chief Education in the Knowledge Society Journal, Universidad de Salamanca, España. fgarcia@usal.es

\section{Resumen}

El editorial de este tercer número del volumen 17, correspondiente al año 2016, está dedicado a destacar la labor del grupo GRIAL por su proyecto de mentorización intercultural INTO, que ha recibido la mención de ejemplo de buenas prácticas y caso de éxito por la Unión Europea.

\section{Palabras clave}

Mentorización; Interculturalidad; Inmigrantes

\begin{abstract}
The editorial of this third issue of volume 17, corresponding to 2016, is devoted to emphasize the well-done activity of the GRIAL research group regarding its intercultural mentoring project INTO, which has received the European Union mention of both example of good practice and success case.
\end{abstract}

\section{Keywords}

Mentoring; Interculturality; Migrants

Me es grato dedicar este editorial para destacar la doble mención que ha recibido el proyecto INTO (INtercultural mentoring TOols to support migrant integration at school) como "Ejemplo de buenas prácticas" y "Caso de éxito" por la por la Dirección General de Educación y Cultura de la Unión Europea (DG EAC). Así se refleja en la Plataforma de Resultados de Proyectos Erasmus+ (http://ec.europa. eu/programmes/erasmus-plus/projects), que muestra la información y resultados de casi 56.000 proyectos financiados dentro de este programa.

INTO es un proyecto europeo Comenius Multilateral (Ref. 540440-LLP-1-2013-1-IT-COMENIUS-CMP) liderado por Oxfam Italia (Carboni, et al., 2013), en el que la Universidad de Salamanca participó como socio a través del Instituto Universitario de Ciencias de la Educación (IUCE) (http://iuce.usal.es) y el GRupo de Investigación en InterAcción y eLearning (GRIAL) (http://grial.usal.es) (García-Peñalvo, 2016b; García-Peñalvo, Rodríguez-Conde, et al., 2012).

Este proyecto, finalizado en octubre de 2015, es un claro ejemplo de la implicación de la Universidad de Salamanca en el desarrollo de la Tercera Misión (Bueno Campos \& Casani, 2007; García-Peñalvo, 2016a; Vilalta, 2013) al definir e implementar estrategias y métodos para ayudar a los estudiantes inmigrantes en riesgo de abandono escolar temprano a mantener su motivación, a través del desarrollo de un innovador modelo y un programa de "Mentorización Intercultural" (No-Gutiérrez, Rodríguez 
Conde, Zangrando, \& Seoane-Pardo, 2015; No-Gutiérrez, Rodríguez Conde, Zangrando, Seoane-Pardo, \& Luatti, 2014).

El panel de expertos de la Unión Europea ha reconocido el proyecto "por su impacto, su contribución al desarrollo de políticas, resultados innovadores y un enfoque creativo que puede ser fuente de inspiración para otros, siguiendo un proceso de selección basado en rigurosos criterios de calidad, relevancia y resultados del proyecto".

Los productos del proyecto, que incluyen manuales de guía para docentes y un kit para docentes y mentores, pueden obtenerse en la web del proyecto: http://www.interculturalmentoring.eu. Asimismo, es posible acceder a un resumen de los resultados del proyecto, en forma de lecciones aprendidas y futuras perspectivas, de gran utilidad para el desarrollo de futuras experiencias: http://www. interculturalmentoring.eu/images/Toolkits/Intercultural_mentoring_tools.pdf. Por último, en el vídeo promocional del proyecto se ofrece un repaso a algunas de las experiencias de mentoría, incluidas las desarrolladas por la Universidad de Salamanca (https://youtu.be/3-gFbnLjdZI).

Este reconocimiento viene a premiar un largo recorrido de investigación que el IUCE y GRIAL vienen desarrollando desde 2009 en proyectos relacionados con la educación intercultural y con enfoques multiculturales (García-Peñalvo, 2013; García-Peñalvo, Zangrando, Seoane Pardo, García Holgado, \& Ovide, 2011; García-Peñalvo, Zangrando, et al., 2012; Popp, et al., 2013; Zangrando, García-Peñalvo, \& Seoane Pardo, 2010).

\section{Contenido de este número}

El primer artículo de este número lleva por título "Gamificación y la Física-Química de Secundaria" (Quintanal Pérez, 2016). Presenta una propuesta de gamificación con estudiantes de $4^{\circ}$ de ESO que han escogido como optativa la materia de Física y Química. La experiencia ha sido un éxito según los resultados obtenidos en la evaluación realizada por los estudiantes.

Jiménez Cortés et al. (2016) presentan un estudio en el que pretenden conocer las habilidades en Internet de las mujeres estudiantes, estableciendo grupos de habilidades más relacionadas con la inclusión digital.

Martínez García y Romero Faz (2016) presentan su experiencia de aplicar, durante varios cursos, técnicas de aprendizaje basado en problemas con el soporte de eLearning y un sistema de acción tutorial con grupos de estudiantes voluntarios de los últimos cursos de la Escuela Técnica Superior de Ingeniería Civil de la Universidad Politécnica de Madrid, logrando incrementar el tiempo de dedicación e implicación con las asignaturas.

El cuarto artículo (Fonseca Escudero, Climent, Canaleta, \& Vicent Safont, 2016) presenta, dentro del 
proyecto Learning4Work (L4W) (financiado por el programa Erasmus+ de la Comunidad Europea), los resultados obtenidos de evaluar la usabilidad del método Scenario Centered Curriculum (SCC), así como el grado de satisfacción de los estudiantes con el mismo, en función del perfil tecnológico de cada grupo de estudiantes. El método se ha introducido en un curso de Marketing Digital impartido en tres escuelas de Formación Profesional de España, Italia y Francia.

El último de los artículos de este número lleva por título "Creación, visualización e impresión 3D de colecciones online de modelos educativos tridimensionales con tecnologías de bajo coste. Caso práctico del patrimonio fósil marino de Canarias" (Saorín Pérez, et al., 2016), en él se describe los procesos de creación y divulgación de un contenido educativo tridimensional e interactivo para aprendizaje en un entorno virtual. Como caso práctico se presenta el trabajo sobre el patrimonio fósil marino canario.

I am pleased to dedicate this editorial to highlight the double mention that INTO (INtercultural mentoring TOols to support migrant integration at school) project has received as "Good practice" and "Success Story" by the by the Directorate General for Education and Culture (DG EAC) of the European Union. This is reflected in the Platform for results Projects Erasmus + (http://ec.europa.eu/programmes/ erasmus-plus/projects) which displays the information and results of almost 56,000 projects funded under this program.

INTO is a European Comenius Multilateral project (Ref. 540440-LLP-1-2013-1-IT-COMENIUS-CMP) led by Oxfam Italy (Carboni et al., 2013), in which University of Salamanca participated as a partner through the Institute for Educational Research (IUCE) (http://iuce.usal.es) and research group in InterAction and eLearning (GRIAL) (http://grial.usal.es) (García-Peñalvo, 2016b; García-Peñalvo, Rodríguez-Conde, et al., 2012).

This project, which finished in October 2015, is a good example of the implication of the University of Salamanca in the development of the Third Mission (Bueno Campos \& Casani, 2007; GarcíaPeñalvo, 2016a; Vilalta, 2013) because of it defines and implements strategies and methods to help migrant students, which are in risk of early school leaving, to maintain their motivation throughout the development of an innovative model and an "Intercultural Mentoring" programme (No-Gutiérrez, et al., 2015; No-Gutiérrez, et al., 2014).

The European Union expert panel has recognised this project due to "its impact, its contribution to policies development, its innovative results, and its creative approach that may be a source of inspiration for others, following a selection process based on rigorous quality and relevance criteria and the project outcomes and outputs".

The outcomes of INTO project, which include tutorials for teacher guidance and a kit for teachers and 
mentors, are available in the project website: http://www.interculturalmentoring.eu. Also, it is possible to access to a summary of the project outcomes by the way of learned lessons and future trends, which are very useful for the development of further experiences: http://www. interculturalmentoring. eu/images/Toolkits/Intercultural_mentoring_tools.pdf. Finally, a review to some of the experiences of mentoring is offered in the promotional video of the project, including those developed by the University of Salamanca (https://youtu.be/3-gFbnLjdZI).

This recognition means a reward to a long way research that IUCE and GRIAL have been developed since 2009 on projects related to intercultural education and multicultural approaches (GarcíaPeñalvo, 2013; García-Peñalvo, et al., 2011; García-Peñalvo, Zangrando, et al., 2012; Popp, et al., 2013; Zangrando et al., 2010).

\section{Contents of this issue}

The first paper of this issues is entitled "Gamification and Physics and Chemistry of Secondary Education" (Quintanal Pérez, 2016). It presents a gamification proposal with students of the fourth course of Secondary Education in Spain that have chosen the Physics and Chemistry optional subject. This experience was a success according to the results of the evaluation by the students.

Jiménez Cortés et al. (2016) make a study oriented to know women's Internet skills, and form different groups of skills of women related with the digital inclusion.

Martínez García and Romero Faz (2016) present their experience about the application, during several academic years, problem-based Learning techniques with the support of eLearning and an action tutorial systems with groups of volunteer students of the last courses of the School of Civil Engineering at the Technical University of Madrid, managing to increase the time of dedication and implication with the subjects.

The fourth paper (Fonseca Escudero, et al., 2016) presents, within the Learning4Work (L4W) project (funded by the European Union Erasmus+ Programme), the results from the evaluation of the usability of the Scenario Centered Curriculum (SCC) method and the students' satisfaction degree with this method, depending on the technological profile of each student group. The method was incorporated into a Digital Marketing course which was taught in three Vocation Training Schools in Spain, Italy and France.

The last paper of this issue is entitled "Creation, visualization and 3D printing of online collections of three dimensional educative models with low-cost technologies. Practical case of Canarian marine fossil heritage" (Saorín Pérez, et al., 2016). This describes the creation and dissemination processes of a three-dimensional, interactive educational content for learning in a virtual environment. As a practical study, authors have worked on the Canary Islands marine fossil heritage. 


\section{Referencias/References}

Bueno Campos, E., \& Casani, F. (2007). La tercera misión de la Universidad. Enfoques e indicadores básicos para su evaluación. Economía Industrial, 366, 43-59.

Carboni, E., Paoletti, M., García-Peñalvo, F. J., Zangrando, V., Rodríguez-Conde, M. J., García-Holgado, A., ... Schulz, J. (2013). Intercultural Mentoring tools to support migrant integration at school (INTO). In F. J. García-Peñalvo, A. García-Holgado, \& J. Cruz-Benito (Eds.), Proceedings of the TEEM'13 Track on Knowledge Society Related Projects (Salamanca, Spain, November 16, 2013) (pp. 53-58). Salamanca, Spain: Grupo GRIAL.

Fonseca Escudero, D., Climent, A., Canaleta, X., \& Vicent Safont, L. (2016). Evaluación del método Scenario Centered Curriculum en función del perfil tecnológico del estudiante. Education in the Knowledge Society, 17(3), 67-88. doi: https://doi.org/10.14201/eks20161736788

García-Peñalvo, F. J. (2013). Multiculturalism in Technology-Based Education: Case Studies on ICTSupported Approaches. Hershey, PA, USA: Information Science Reference.

García-Peñalvo, F. J. (2016a). La tercera misión. Education in the Knowledge Society, 17(1), 7-18. doi:https://doi.org/10.14201/eks2016171718

García-Peñalvo, F. J. (2016b). Presentation of the GRIAL research group and its main research lines and projects on March 2016. Retrieved from http://hdl.handle.net/10366/127737

García-Peñalvo, F. J., Rodríguez-Conde, M. J., Seoane-Pardo, A. M., Conde-González, M. Á., Zangrando, V., \& García-Holgado, A. (2012). GRIAL (GRupo de investigación en InterAcción y eLearning), USAL. IE Comunicaciones. Revista Iberoamericana de Informática Educativa(15), 85-94.

García-Peñalvo, F. J., Zangrando, V., Seoane Pardo, A. M., García Holgado, A., \& Ovide, E. (2011). Learning European history and geography in a multicultural and ICT perspective. International Journal of Technology Enhanced Learning (IJTEL), 3(4), 343-354. doi:http://dx.doi.org/10.1504/ IJTEL.2011.041278

García-Peñalvo, F. J., Zangrando, V., Seoane Pardo, A. M., García Holgado, A., Szczecinska, J., Baldner, J. M., ... Crivellari, C. (2012). Multicultural Interdisciplinary Handbook. Tools for Learning History and Geography in a Multicultural Perspective. Salamanca, Spain: Research GRoup in InterAction and eLearning.

Jiménez Cortés, R., Vega Caro, L., \& Vico Bosch, A. (2016). Habilidades en Internet de mujeres 
estudiantes y su relación con la inclusión digital: Nuevas brechas digitales. Education in the Knowledge Society, 17(3), 29-48. doi: https://doi.org/10.14201/eks20161732948

Martínez García, M., \& Romero Faz, D. (2016). Aprendizaje Basado en Problemas mediante un modelo de Teleenseñanza. Education in the Knowledge Society, 17(3). doi: https://doi.org/10.14201/ eks20161734966

No-Gutiérrez, P., Rodríguez Conde, M. J., Zangrando, V., \& Seoane-Pardo, A. M. (2015). Assessment of the intercultural mentoring programme. In G. R. Alves \& M. C. Felgueiras (Eds.), Proceedings of the Third International Conference on Technological Ecosystems for Enhancing Multiculturality (TEEM'15) (Porto, Portugal, October 7-9, 2015) (pp. 349-354). New York, NY, USA: ACM.

No-Gutiérrez, P., Rodríguez Conde, M. J., Zangrando, V., Seoane-Pardo, A. M., \& Luatti, L. (2014). Peer tutoring at school with migrant students: intercultural mentoring programme. In F. J. García-Peñalvo (Ed.), Proceedings of the Second International Conference on Technological Ecosystems for Enhancing Multiculturality (TEEM'14). Salamanca, Spain, October 7-3, 2014 (pp. 483-487). New York, NY, USA: ACM.

Popp, S., Schumann, J., Simmet, O., Szczecińska, J., Hadrysiak, S., Haydn, T., . . Friz, S. (2013). European history crossroads as pathways to intercultural and media education (EHISTO). In F. J. García-Peñalvo, A. García-Holgado, \& J. Cruz-Benito (Eds.), Proceedings of the TEEM'13 Track on Knowledge Society Related Projects (Salamanca, Spain, November 16, 2013) (pp. 31-35). Salamanca, Spain: Grupo GRIAL.

Quintanal Pérez, F. (2016). Gamificación y la Física-Química de Secundaria. Education in the Knowledge Society, 17(3), 13-28. doi: https://doi.org/10.14201/eks20161731328

Saorín Pérez, J. L., Torre Cantero, J., Meier, C., Melián Díaz, M., Ruiz Castillo, C., \& Bonnet de León, A. (2016). Creación, visualización e impresión 3D de colecciones online de modelos educativos tridimensionales con tecnologías de bajo coste. Caso práctico del patrimonio fósil marino de Canarias. Education in the Knowledge Society, 17(3),89-108. doi: https://doi.org/10.14201/eks201617389108

Vilalta, J. M. (2013). La tercera misión universitaria. Innovación y transferencia de conocimientos en las universidades españolas. Madrid: Studia XXI. Fundación Europea Sociedad y Educación.

Zangrando, V., García-Peñalvo, F. J., \& Seoane Pardo, A. M. (2010). Multicultural Interdisciplinary Handbook (MIH): Tools for Learning History and Geography in a Multicultural and ICT Perspective. In M. D. Lytras, P. O. DePablos, D. Avison, J. Sipior, Q. Jin, W. Leal, L. Uden, M. Thomas, S. Cervai, \& D. Horner (Eds.), Technology Enhanced Learning: Quality of Teaching and Educational Reform. 1st International Conference, TECH-EDUCATION 2010, Athens, Greece, May 19-21, 2010. Proceedings (Athens, Greece, May 19-21, 2010) (pp. 374-378). Berlin, Heidelberg: Springer. 